\title{
CHANGES IN THE TROPHIC STATUS OF LAKE NIEPRUSZEWSKIE (POLAND)
}

\author{
Janina Zbierska' ${ }^{1}$ Agnieszka E. Ławniczak' ${ }^{1}$, Anna Zbierska²
}

1 Department of Ecology and Environmental Protection, Poznań University of Life Sciences, Piątkowska Str. 94C, 60-649 Poznań, Poland, e-mail: jzbier@up.poznan.pl; lawnic@up.poznan.pl

2 Institute of Land Reclamation, Environmental Management and Geodesy, Poznań University of Life Sciences, Piątkowska Str. 94E, 60-649 Poznań, Poland, e-mail: anzbier@up.poznan.pl

Received: 2015.07 .16

Accepted: 2015.08.31

Published: 2015.10.01

\begin{abstract}
The paper presents the evaluation of trophic status of Lake Niepruszewskie in the years 1994-2013. This is the first lake in the Samica Stęszewska river, flowing distally through the lakes of the Wielkopolski National Park. Source part of the Samica Stęszewska river basin was, in the years 2004-2012, included to the nitrate vulnerable zone (NVZ), and Niepruszewskie Lake was considered to be threatened by eutrophication. The evaluation of trophic status of the lake was made based on the concentration of nutrients (nitrogen and phosphorus) and indicators of eutrophication (chlorophyll $a$, water transparency Secchi disk marked) by referring them to the limit values for the eutrophication of surface waters as defined in the Regulation of the Minister of Environment of 23 December 2002 and other criteria used for the classification of the eutrophication of surface waters. Detailed and synthetic indexes of the trophic status (TSI) using the formula Carlson and the ratio of N:P were also made. Concentrations of the nutrients in Lake Niepruszewskie and eutrophication indexes reached high values, indicating a eutrophic or hypertrophic state of the lake. Detailed values of the trophic status index (TSI), on average over the period, corresponded to eutrophic, while in subsequent years they were varied - from mesotrophic to hypertrophic. The worst trophic status was recorded in 2003-2006, after the lowering of the lake damming. The high value of N: P ratio indicates that the lake has huge surplus of nitrogen, and phosphorus is a productivity limiting factor.
\end{abstract}

Keywords: nitrogen, phosphorus, chlorophyll $a$, water transparency, trophic status index.

\section{INTRODUCTION}

Eutrophication is one of the greatest threats to aquatic ecosystems [Carlson 1977, Galvez-Cloutier and Sanchez 2007, Hillbricht-Ilkowska 1989, Kajak 1983, Nürnberg 2001, Pełechata et al. 2006, Soszka 2009, Szymański et al. 2014]. It is the enrichment of water in biogenic components (mainly nitrogen and phosphorus), resulting in the intensive development of phytoplankton and higher aquatic plants, resulting in the disruption of biological relations in the deterioration of the aquatic environment and the quality of these. Eutrophication is a slow and long process, but in the twentieth century its intensity was marked as a result of anthropogenic impacts. The largest contribution to eutrophication was the result of im- proper sewage handling including increasing, until the 1980's, the amount of wastewater requiring treatment and its insufficient cleaning. Protection of water against eutrophication in Poland began only in the mid-1990's, when sewage treatment plants introduced a heightened degree of nutrients removal. In 1995 , only $2.7 \%$ sewage were subject to treatment with an elevated removal of nutrients, while in 2013 it was already 49\% [Environment 2005, 2014]. Nitrogen load in urban waste water discharged after treatment, amounting to 30.2 thousand tons in 1995, decreased in 2013 to 24 thousand tons, while the phosphorus load has decreased in this period from 6.9 thousand tons to 1.3 thousand tons [Environment 2005, 2014].

Agriculture is also a significant source of nutrient pollution to water, especially intensive 
fertilization of field crops and livestock concentration [Fotyma and Duer 2006, Karaczun 2005, OECD 2003, OECD 2008]. Protection of water against pollution from agriculture were started in Poland only in 2004, upon the designation of waters affected by pollution and nitrates vulnerable zones (NVZ), which should reduce pollution of water by nitrates - in accordance with the requirements of the Nitrates Directive [Directive 91/676/EEC]. In the period 2004-2012 the highest NVZ was determined in Wielkopolska region, including NVZ of Samica Stęszewska, where the studied Lake Niepruszewskie was located [Rozporządzenie... 2003, 2008].

The aim of the study was to determine the degree of eutrophication of Lake Niepruszewskie and the assessment of changes in the trophic status of the lake in the years between 1994-2013 in terms of threat of water and protection activities.

\section{STUDY AREA}

Lake Niepruszewskie (surface water body code: LW10134) is located in mesoregion Poznań Lakeland (Pojezierze Poznańskie, 315.51), which forms the western part of macro-region of Wielkopolskie Lakeland (Pojezierze Wielkopolskie, 325.5) [Kondracki 2000]. It is the first lake in the river Samica Stęszewska, which further flows through the lakes: Tomickie, Witobelskie and Łódzko-Dymaczewskie (the latter two are within the boundaries of the Wielkopolski National Park) and flows into the Mosiński Chanel - left bank tributary of the Warta river. It is a lake gutter with a longitudinal axis close to the north - south direction, powered mainly by Samica Stęszewska river and drainage ditches of adjacent fields and meadows. Lake Niepruszewskie is of a type $3 \mathrm{~b}$ - it is a lake with a high content of calcium, high impact of catchment, non-stratified, with a coefficient of Schindler $>2$.

The total catchment of the lake (Figure 1) covers an area of $50.57 \mathrm{~km}^{2}$, while the direct catchment area amounts to $6.97 \mathrm{~km}^{2}$ [Atlas... 2005]. The area of catchment has agricultural character (arable land amounts to $68.4 \%$ of the surface) and is characterized by intensive economy and high agricultural culture [ and Zbierska 2006]. Forests occupy only about $12 \%$ of the catchment area. The areas adjacent to the lake are in a form of semi-urban areas with buildings of the village Niepruszewo and Cieśle from the western side, Kalwy about $0.5 \mathrm{~km}$ north and Więckowice and Zborowo on the eastern side. The village Niepruszewo has baths, and Zborowo has a place for bathing. On the western part of the lake, lying within the municipality of Buk, motorboats equipment is allowed to use for four days a week.

The water level in Lake Niepruszewskie is controlled by a weir located at the outlet of the Samica Stęszewska river of this reservoir and this is the reason why the lake area and its volume are significantly affected [Ławniczak et al. 2011, Murat-Błażejewska et al. 2008]. In the years 1976-2002 the damming allowed the retention of approx. 2 million $\mathrm{m}^{3}$ of water, which until 1990 was used for agricultural irrigation and for diluting the liquid manure used in agriculture. Lake Niepruszewskie is characterized by high susceptibility to degradation (III category), which is determined by: a small depth (average $3.05 \mathrm{~m}$, maximum 4.8), no stratification of water, the ratio of the bottom active surface to the volume of epilimnion (0.33) and a significant basin elongation (length of approx. $4900 \mathrm{~m}$, average width of approx. $500 \mathrm{~m}$ ), length of 11.3 kilometres of coastline. The large surface of the active bottom and intensive mixing of water create the conditions for the release of nutrients from the bottom sediments, which may increase the eutrophication process even after reducing off the external inflow.

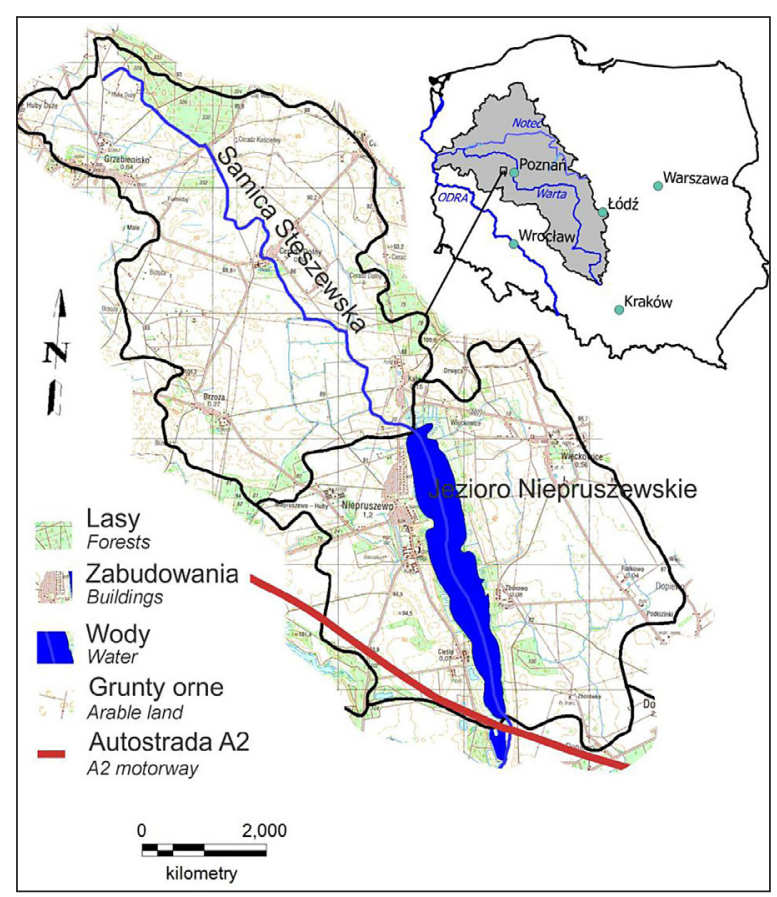

Figure 1. The catchment area of Lake Niepruszewskie [catchment border according to Atlas... 2005] 
In the years 2004-2012 the Samica Stęszewska river, to the section at the outlet of Niepruszewskie Lake, was included in the waters vulnerable to pollution from nitrogen compounds from agricultural sources [Rozporządzenie... 2003, Rozporządzenie... 2008], and the Niepruszewskie Lake was considered to be at risk of eutrophication, because they met the conditions set out in the Nitrates Directive [Directive 91/676/EEC] and in the Regulation of the Minister of Environment of 23 December 2002 [Rozporządzenie... 2002].

\section{MATERIAL AND METHODS}

Water quality tests were performed in 19992003 twice a year (spring and summer), according to the methodology for lakes monitoring, while in 2005-2008 the tests were performed 5-7 times a year, mainly in the growing season. Total phosphorus was determined by a colorimetric method (after persulfate mineralization in an acidic environment), total nitrogen by Kjeldahl method, chlorophyll $a$ was determined according to $\mathrm{PN}-88 / \mathrm{C}-04632-040$, water transparency was measured by Secchi disk. The data for the years 1994, 2003 and 2009-2013 are derived from water monitoring conducted by the Regional Inspectorate of Environmental Protection in Poznań.

To evaluate the trophy of water the limit values indicative of eutrophication of water were used, as defined in the Regulation of the Minister of Environment of 23 December 2002 on the criteria for the designation of waters vulnerable to pollution from nitrogen compounds from agricultural sources [Rozporządzenie... 2002], as well as the criteria developed by Nurnberg [2001], Forsberg and Ryding [1980], Kajak [1983] and HilbrichtIlkowska [1989] and used in the classification of the OECD [1982]. The evaluation of trophic status of the lake was also made on the basis of the trophic status indexes (TSI) of Carlson (1977), taking into account the content of chlorophyll $a$ (Chl), concentration of the total phosphorus in water (TP) and water transparency determined by Secchi disk (SD) in summer (July - August).

Values of indicators were calculated according to formulas:

$$
\begin{gathered}
\mathrm{TSI}(\mathrm{Chl})=9.81 \ln (\mathrm{Chl})+30.6 \\
\mathrm{TSI}(\mathrm{SD})=60-14.43 \ln (\mathrm{SD}) \\
\mathrm{TSI}(\mathrm{TP})=14.43 \ln (\mathrm{TP})+4.15 \\
\mathrm{TSI}(\mathrm{TN})=54.45+14.43 \ln (\mathrm{TN}) \\
\mathrm{TSI}=[\mathrm{TSI}(\mathrm{Chl})+\mathrm{TSI}(\mathrm{SD})+\mathrm{TSI}(\mathrm{TP})] / \mathrm{n}
\end{gathered}
$$

where: TSI - trophic status index,

ln - natural logarithm,

$\mathrm{n}$ - number of indexes.

The value of indicator varies from 0 to 100 , and each class of the trophic status is assigned with the following value ranges: $0-40$-oligotrophic 40-50-mesotrophic 50-70-eutrophic, 70100 - hypertrophic.

\section{RESULTS AND DISCUSSION}

The study showed big differences in the concentrations of nutrients and indicators of eutrophication in Lake Niepruszewskie (Table 1). Total phosphorus concentration throughout the test period reached a mean value of $0.092 \mathrm{mg} \mathrm{P} /$ $\mathrm{dm}^{3}$, while in each period it ranged from 0.031 to $0.16 \mathrm{mg} \mathrm{P} / \mathrm{dm}^{3}$. The concentration reached the highest values in 2001 and 2003 to 2006, when it far exceeded the limit above which eutrophication occurs [Rozporządzenie... 2002]. Fairly high concentrations of phosphorus, close to the border value, were also recorded in 1999-2000 and 2007-2008. In the last three analysed years the reduction in the concentration of this component has been marked. According to most of the criteria, concentrations of phosphorus indicated eutrophy and hypertrophy, only in 2009 according to OECD criteria (1982) the level of phosphorus corresponded to mesotrophy (Table 2). The result was slightly different when rating by the criteria proposed by Kajak [1983] and Hilbricht-Ilkowska [1989], by which the concentration of phosphorus in the lake corresponded to mesotrophy and eutrophy. The concentration of phosphorus in Lake Niepruszewskie was lower than in urban lakes of Olsztyn (Poland) [Szymański et al. 2014], some lakes of catchment area the river Stupia (Poland) [Jarosiewicz 2011] and Lubuskie Lakeland (Poland)[Pełechata et al. 2006], and also much larger than most lakes in Quebec province (Canada) [Galvez-Cloutier and Sanchez 2007].

The concentration of chlorophyll $a$ in the water of the lake ranged from 21.4 to $90.9 \mathrm{mg} / \mathrm{dm}^{3}$ and until 2007 it considerably exceeded the limit value indicative of eutrophication, only in the last two years (2009-2010) it was slightly below this limit (Table 1). The highest values of this parameter were recorded in 2003 and 2005, directly after the lowering of the lake water damming in the second half of 2002. In the same period a very high concentration of total phosphorus was also 
Table 1. Eutrophication indexes values observed in Lake Niepruszewskie

\begin{tabular}{|c|c|c|c|c|}
\hline Year & Total phosphorus $\left(\mathrm{mg} \mathrm{P} / \mathrm{dm}^{3}\right)$ & Chlorophyll a $\left(\mu \mathrm{g} / \mathrm{dm}^{3}\right)$ & Secchi depth $(\mathrm{m})$ & Total nitrogen $\left(\mathrm{mg} \mathrm{N} / \mathrm{dm}^{3}\right)$ \\
\hline 1994 & 0.044 & 65.0 & 1.00 & - \\
\hline 1999 & 0.085 & 34.9 & 0.78 & - \\
\hline 2000 & 0.097 & 55.6 & 0.92 & - \\
\hline 2001 & 0.145 & 57.8 & 1.21 & - \\
\hline 2002 & 0.085 & 54.1 & 1.24 & - \\
\hline 2003 & 0.133 & 71.3 & 0.80 & 3.50 \\
\hline 2005 & 0.160 & 90.9 & 0.53 & 4.94 \\
\hline 2006 & 0.120 & 54.7 & 0.40 & 4.19 \\
\hline 2007 & 0.080 & 39.3 & 0.80 & 4.06 \\
\hline 2008 & 0.090 & 27.6 & 0.82 & 4.14 \\
\hline 2009 & 0.031 & 21.4 & 0.96 & 4.37 \\
\hline 2010 & 0.069 & 22.5 & 1.05 & 4.20 \\
\hline 2013 & 0.052 & - & 1.00 & $>1.5$ \\
\hline Average & 0.092 & 49.6 & 0.89 & $<2.0$ \\
\hline Limit values & $>0.1$ & $>25$ & $<$ & - \\
\hline
\end{tabular}

* Values defined in the Regulation of the Minister of Environment of 23 December 2002 on the criteria for the designation of waters vulnerable to pollution from nitrogen compounds from agricultural sources [Rozporządzenie... 2002]

Table 2. Trophic state of the Lake Niepruszewskie

\begin{tabular}{|c|c|c|c|c|c|c|c|c|c|c|c|c|}
\hline \multirow{2}{*}{ Year } & \multicolumn{3}{|c|}{ OECD [1982] } & \multicolumn{3}{|c|}{ Nürnberg [2001] } & \multicolumn{3}{|c|}{$\begin{array}{c}\text { Forsberg and Ryding } \\
\text { [1980] }\end{array}$} & \multicolumn{3}{|c|}{$\begin{array}{c}\text { Kajak [1983] and } \\
\text { Hilbricht-Ilkowska [1989] }\end{array}$} \\
\hline & TP & Chl & SD & TP & Chl & $\mathrm{TN}$ & TP & Chl & $\mathrm{TN}$ & TP & $\mathrm{Chl}$ & $\mathrm{TN}$ \\
\hline 1994 & $E^{*}$ & $\mathrm{H}$ & $\mathrm{H}$ & $E$ & $\mathrm{H}$ & - & $E$ & $\mathrm{H}$ & - & $\mathrm{M}$ & $E$ & - \\
\hline 1999 & $E$ & $\mathrm{H}$ & $\mathrm{H}$ & $E$ & $\mathrm{H}$ & - & $E$ & $E$ & - & $\mathrm{ME}$ & $E$ & - \\
\hline 2000 & $E$ & $\mathrm{H}$ & $\mathrm{H}$ & $E$ & $\mathrm{H}$ & - & $E$ & $\mathrm{H}$ & - & $\mathrm{ME}$ & $\mathrm{E}$ & - \\
\hline 2001 & $\mathrm{H}$ & $\mathrm{H}$ & $\mathrm{H}$ & $\mathrm{H}$ & $\mathrm{H}$ & - & $\mathrm{H}$ & $\mathrm{H}$ & - & $E$ & $E$ & - \\
\hline 2002 & $E$ & $\mathrm{H}$ & $\mathrm{H}$ & $E$ & $\mathrm{H}$ & - & $E$ & $\mathrm{H}$ & - & ME & $E$ & - \\
\hline 2003 & $\mathrm{H}$ & $\mathrm{H}$ & $\mathrm{H}$ & $\mathrm{H}$ & $\mathrm{H}$ & - & $\mathrm{H}$ & $\mathrm{H}$ & - & $E$ & $E$ & - \\
\hline 2005 & $\mathrm{H}$ & $\mathrm{H}$ & $\mathrm{H}$ & $\mathrm{H}$ & $\mathrm{H}$ & - & $\mathrm{H}$ & $\mathrm{H}$ & - & $E$ & $E$ & - \\
\hline 2006 & $\mathrm{H}$ & $\mathrm{H}$ & $\mathrm{H}$ & $\mathrm{H}$ & $\mathrm{H}$ & $\mathrm{H}$ & $\mathrm{H}$ & $\mathrm{H}$ & $\mathrm{H}$ & $E$ & $E$ & $E$ \\
\hline 2007 & $E$ & $\mathrm{H}$ & $\mathrm{H}$ & $E$ & $\mathrm{H}$ & $\mathrm{H}$ & $E$ & $E$ & $\mathrm{H}$ & $\mathrm{ME}$ & $E$ & $E$ \\
\hline 2008 & $E$ & $\mathrm{H}$ & $\mathrm{H}$ & $E$ & $\mathrm{H}$ & $\mathrm{H}$ & $E$ & $E$ & $\mathrm{H}$ & $\mathrm{ME}$ & ME & $E$ \\
\hline 2009 & $M$ & $E$ & $\mathrm{H}$ & $E$ & $\mathrm{H}$ & $\mathrm{H}$ & $E$ & $\mathrm{E}$ & $\mathrm{H}$ & $\mathrm{M}$ & ME & E \\
\hline 2010 & $E$ & $E$ & $\mathrm{H}$ & $E$ & $\mathrm{H}$ & $\mathrm{H}$ & $E$ & $E$ & $\mathrm{H}$ & $\mathrm{ME}$ & ME & $E$ \\
\hline 2013 & $E$ & - & $\mathrm{H}$ & $E$ & - & $\mathrm{H}$ & $E$ & - & $\mathrm{H}$ & $\mathrm{ME}$ & - & $E$ \\
\hline Average & $E$ & $\mathrm{H}$ & $\mathrm{H}$ & $E$ & $\mathrm{H}$ & $\mathrm{H}$ & $E$ & $\mathrm{H}$ & $\mathrm{H}$ & ME & E & E \\
\hline
\end{tabular}

* M - mesotrophy; ME - mesoeutrophy, E - eutrophy, H - hypertrophy.

recorded. The average concentration of chlorophyll $a$, according to most criteria [Forsberg and Ryding 1980, Nürnberg 2001, OECD 2008] indicated a state of hypertrophy, only according to the criteria of Kajak [1983] and Hilbricht-Ilkowska [1989] it corresponded to eutrophy. For most of the period concentrations of chlorophyll indicated a high trophic status (hypertrophic) and only in recent years it has slightly decreased - to the eutrophic state according to the criteria of Fors- berg and Ryding [1989] in 2007-2010, according to OECD [2008] criteria only in 2009-2010. Also according to the criteria of Kajak [1983] and Hilbricht-Ilkowska [1989] trophic status of lakes in 2008-2010 decreased to mesoeutrophic. The level of chlorophyll in the studied lake was much higher than in urban lakes of Olsztyn [Szymański et al. 2014], in the majority of lakes of the catchment area of the river Stupia [Jarosiewicz 2011] and Lubuskie Lakeland [Pełechata et al. 2006], 
or in lakes in Quebec Province (Canada) [GalvezCloutier and Sanchez 2007].

Transparency of water measured by Secchi disk throughout the analyzed period was below the size limit specified for the eutrophication of surface waters [Rozporządzenie... 2002]. On average over the period it amounted to only 0.89 $\mathrm{m}$, and in the individual years it ranged from 0.4 $\mathrm{m}$ in 2006 to $1.24 \mathrm{~m}$ in 2002 (Table 1). In 2002, the lake has been loaded with plenty of rainwater and thaw water in the spring period and the highest accumulation of water in the basin occurred, which could affect the dilution of pollutants and improve water transparency. The worst lighting conditions occurred in 1999-2000 and 2003-2009 (less than $1 \mathrm{~m}$ ). The deterioration in Secchi disk visibility was usually associated with intensive development and the phytoplankton blooms (higher concentration of chlorophyll), but in recent years it could also be the result of water turbidity caused by the motorboats equipment used for recreational purposes, causing intensive

Table 3. Values of N:P ratio in water of Lake Niepruszewskie

\begin{tabular}{|c|c|}
\hline Years & N:P ratio \\
\hline 2006 & 29 \\
\hline 2007 & 62 \\
\hline 2008 & 47 \\
\hline 2009 & 131 \\
\hline 2010 & 60 \\
\hline 2013 & 84 \\
\hline Average & $\mathbf{6 9}$ \\
\hline
\end{tabular}

mixing of water and lifting of sediments. According to OECD criteria (2008) low transparency of water indicated a status of hypertrophy in all years (Table 1).

The concentration of total nitrogen in the lake analyzed since 2006 was throughout the entire period very high and more than twice exceeded the threshold for eutrophication (Table 1) [Rozporządzenie... 2002]. Both according to the criteria of Forsberg and Ryding [1989] and Nuremberg [2001] it pointed to the status of hypertrophy, and according to the criteria of Kajak [1983] and Hilbricht-Ilkowska [1989] - to eutrophic status. The ratio of the concentration of nitrogen $(\mathrm{N})$ and phosphorus in water $(\mathrm{P})$ analyzed since 2006, was 69 on average, while in the whole period it ranged from 29 in 2006 to 131 in 2009 (Table 3). This indicates that the lake has large surpluses of nitrogen and phosphorus is mainly a limiting factor of productivity.

The values of trophic status index (TSI) calculated based on formulas of Carlson [1977], on average, over the analyzed period corresponded to eutrophy, while they were varied in the subsequent years (Table 4). Among the partial indicators of the trophic, the highest average value reached TSI(Chl), calculated based on the concentration of chlorophyll $a$, which amounted to 67.5 and was in the upper level of eutrophic range. In subsequent years, this index ranged from 59.5 in 2010 (eutrophy) to 72.5 in 2003 (hypertrophy). The highest values were reached by this index in 1994 and 2000-2006, when they exceeded or were close to the criterion for hypertrophy.

Table 4. Value of Carlson trophic state indexes (TSI) of Lake Niepruszewskie

\begin{tabular}{|c|c|c|c|c|c|c|}
\hline Year & TSI(TP) & Trophic status & TSI(Chl) & Trophic status & TSI(SD) & Trophic status \\
\hline 1994 & 67.3 & $\mathrm{E}^{*}$ & 71.5 & $\mathrm{H}$ & 60.0 & $\mathrm{E}$ \\
\hline 1999 & 60.5 & $\mathrm{E}$ & 65.4 & $\mathrm{E}$ & 63.6 & $\mathrm{E}$ \\
\hline 2000 & 70.6 & $\mathrm{H}$ & 70.0 & $\mathrm{E}$ & 61.2 & $\mathrm{E}$ \\
\hline 2001 & 75.4 & $\mathrm{H}$ & 70.4 & $\mathrm{H}$ & 57.3 & $\mathrm{E}$ \\
\hline 2002 & 69.0 & $\mathrm{E}$ & 72.3 & $\mathrm{H}$ & 56.8 & $\mathrm{E}$ \\
\hline 2003 & 78.3 & $\mathrm{H}$ & 72.5 & $\mathrm{H}$ & 63.2 & $\mathrm{E}$ \\
\hline 2005 & 74.4 & $\mathrm{H}$ & 68.9 & $\mathrm{E}$ & 69.9 & $\mathrm{E}$ \\
\hline 2006 & 70.6 & $\mathrm{H}$ & 67.9 & $\mathrm{E}$ & 77.3 & $\mathrm{H}$ \\
\hline 2007 & 67.3 & $\mathrm{E}$ & 66.3 & $\mathrm{E}$ & 65.2 & $\mathrm{E}$ \\
\hline 2008 & 74.4 & $\mathrm{H}$ & 62.9 & $\mathrm{E}$ & 64.8 & $\mathrm{E}$ \\
\hline 2009 & 53.2 & $\mathrm{E}$ & 62.2 & $\mathrm{E}$ & 69.4 & $\mathrm{E}$ \\
\hline 2010 & 47.4 & $\mathrm{M}$ & 59.5 & $\mathrm{E}$ & 59.6 & $\mathrm{E}$ \\
\hline 2013 & 55.1 & $\mathrm{E}$ & - & - & 60.0 & $\mathrm{E}$ \\
\hline Average & 66.4 & $\mathrm{E}$ & $\mathbf{6 7 . 5}$ & $\mathrm{E}$ & $\mathbf{6 3 . 7}$ & $\mathrm{E}$ \\
\hline
\end{tabular}

* E - eutrophy; M - mesotrophy; H - hypertrophy. 
The value of the partial indicator of the trophic status of the TSI(TP), based on total phosphorus concentration, was slightly lower and amounted to an average of 66.4 , which also corresponds to eutrophic class. During the study period, this index ranged from 47.7 in 2010 (mesotrophy) to 78.3 in 2003 (hypertrophy). Clearly higher values of this index occurred in 2000-2008, when the exceeded the limit adopted for hypertrophy, or were close to it. TSI(SD) trophic status indicator, calculated based on water transparency marked by Secchi disk, reached an average value of 63.7, corresponding to eutrophy. Almost throughout the entire analysed period it was placed within the range corresponding to eutrophy, from 56.8 in 2002 to 69.9 in 2005, only in 2006 it clearly crossed the line adopted for hypertrophy. Compared with the lakes of Olsztyn, TSI(TP) index in the studied lake reached similar or lower values, the index TSI(Chl) was comparable, while the TSI(SD) index was significantly higher [Szymański et al. 2014]. Indexes: TSI(TP) and TSI(SD) were comparable to those listed in lakes of Lubuskie Lakeland [Pełechata et al. 2006].

The synthetic index of the trophic status of the TSI throughout the study period achieved an average value of 65.6 and showed the eutrophic status of Lake Niepruszewskie (Table 4). The highest values were reached in the period 2003-2006, when it showed the hypertrophic status. The lowest values were founded in 2010 and 2013, while in other years they remained at the upper level of the eutrophic state $(>61)$. Analysis of changes of TSI synthetic index lead to the observation of clear deterioration of the trophic status of Lake Niepruszewskie in 2003-2006, immediately after the lowering of the lake water damming in the second half of 2002 (Figure 2).
This could be due to the deterioration of the hydrological conditions in the lake. In the second half of 2002, because of strong pressure of owners of the parcels located in the vicinity of the lake along with the recession in agriculture and the lack of interest in further consumption of water for irrigation, the level of water damming was reduced in the basin by an average of approx. $0.45 \mathrm{~m}$ (i.e. $16.7 \%$ of average depth), which resulted in a decrease and the volume of water in the lake by approx. 1.3 million $\mathrm{m}^{3}$ and a the decrease of the surface of the lake to 253 ha [Ławniczak et al. 2011, Murat-Błażejewska et al. 2008]. In 2001-2002, the average annual amplitude of water level was $94 \mathrm{~cm}$ and was twice as high as in 2003-2007. In addition, in 2003 there was very little precipitation, amounting to $355 \mathrm{~mm}$ in the catchment area (it means $70 \%$ of the average rainfall in the period 1971-2000), which has exacerbated a shortage of water in the lake [Zbierska et al. 2011]. In 2003 there was an extremely low water level in the lake, $76.06 \mathrm{~m}$, this means below the brink of weir. This resulted in the inhibition of the outflow of water from the lake through the river Samica Stęszewską and greatly reduced flows continued in its course, including their periodic disappearance [Zbierska et al. 2011]. In 2004, rainfall amounted to $463 \mathrm{~mm}$, and it was also lower than the average of the multi-year (92\%), which prolonged the persistence of unfavourable hydrological conditions. Quick draining water from the lake in 2002 and the subsequent lowering of the water level had a negative impact not only on the quality of water in the Lake Niepruszewskie, but also in lakes located lower in the flow of the river Samica Stęszewska, especially in the immedi-

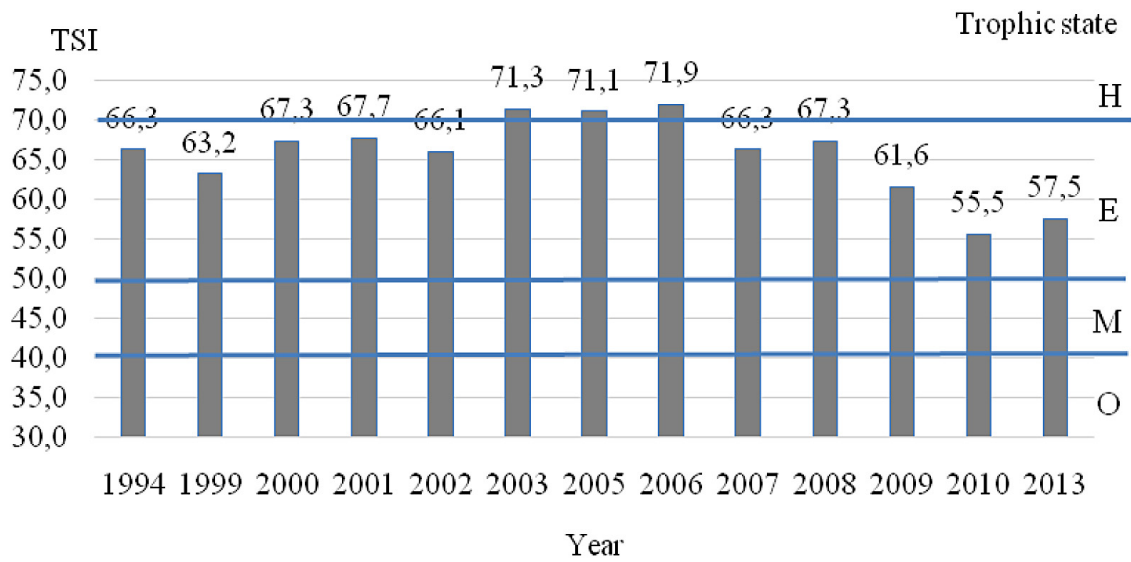

Figure 2. Changes of the Niepruszewskie Lake trophic state on the basis of Carlson index mean value TSI(TP+Chl+SD); O - oligotrophy, M - mesotrophy, E - eutrophy, H - hypertrophy 
ate Lake Tomickie, which increased $\mathrm{BOD}_{5}$ and concentration of phosphates and phosphorus, chlorophyll $a$ and seston and decreased Secchi depth, whereby the water quality class III deteriorated to a status outside the classes [Zbierska and Kupiec 2004].

Lake trophic indexes improvement noticeable since 2009 could be due to sorting waste water management in localities located on the lake and the implementation on the catchment area of action programs aimed at reducing the outflow of nitrogen from agricultural sources. In 2008 a sewage treatment plant in Niepruszewo was put into operation and in the years 20092012 a sewage system in the villages Niepruszewo and Cieśle was built [Zbierska et al. 2011]. In the years 2004-2012 action programs were implemented in the catchment area concerning the existing intensive farming and livestock production, consisting of, among others, the application of good agricultural practice, preparation of plans for the balance of ingredients and fertilizer, building panels and tanks for the storage of organic fertilizers [Rozporządzenie... 2004, 2008]. Unfortunately, after OSN verification in 2012 these programs in the catchment area are no longer implemented.

By analysing the relationship between partial indexes, it can be observed that their average value of the entire period did not differ significantly. The highest value was reached by chlorophyll $a$ TSI(Chl), while other indexes were slightly lower. It can therefore be assumed that this relationship becomes: $\mathrm{TSI}(\mathrm{TP})=\mathrm{TSI}(\mathrm{Chl})=\mathrm{TSI}(\mathrm{SD}$. This points to the intensive development of phytoplankton in trophic favourable conditions and its impact on the deteriorating of light conditions in the lake. In subsequent years these relations showed greater variation. Analysing the data in the table 4, it can be found that by 2002 the ratio was generally in accordance with the formula TSI(Chl) $=\mathrm{TSI}(\mathrm{TP})>\mathrm{TSI}(\mathrm{SD})$, which indicates the dominance of large particles of algae and the possibility of the presence of blue-green algae. Between 2005 and 2008 the greatest value was achieved by TSI(TP), much lower by TSI(SD), and the lowest had the index of chlorophyll TSI(Chl), which may indicate the effect of other factors on deterioration of light, e.g. suspensions or toxins. In 2006, TSI(SD) index achieved significantly greater value than the other two indicators with similar values, reflecting the dominance of small algae limiting the Secchi depth. The smoothed values of the indicators in 2007 showed deteriorating light conditions in the lake as a result of growth of phytoplankton in favorable trophic conditions. Recent years 2009-2013 revealed a relationship $\mathrm{TSI}(\mathrm{SD})=\mathrm{TSI}(\mathrm{Chl})>\mathrm{TSI}(\mathrm{TP})$, that points to the limiting effect of phosphorus on the growth of algae.

\section{CONCLUSIONS}

1. Lake Niepruszewskie should be classified as eutrophic because most of the analysed indicators exceed the limits specified in the national legislation, including the transparency of water and nitrogen concentration throughout the study period (1994-2013), the concentration of chlorophyll in 2008, while the total phosphorus concentration only occasionally.

2. Trophic status of Lake Niepruszewskie, determined on the basis of various scientific criteria, in relation to the total phosphorus levels should be defined as eutrophic, but due to the concentration of chlorophyll, Secchi depth and concentration of nitrogen as hypertrophic. This was also confirmed by Carlson trophic state index values (TSI), most of which correspond to eutrophy, but they also increased periodically to hypertrophy.

3. The high value of $\mathrm{N}: \mathrm{P}$ ratio indicates that the lake had large surpluses of nitrogen, and phosphorus was a limiting factor of productivity. Relationships between partial indexes of TSI(TP), TSI(Chl) and TSI(SD) showed that the lake appeared abundant with phytoplankton development, which most often was the cause of the reduction of water transparency. Periodically, the deterioration of the light conditions in the lake could also be affected by other factors, including turbidity caused by the use of motorboats equipment.

4. Significant deterioration of the trophic status of Lake Niepruszewskie occurred in 20032006 in connection with the deterioration of the hydrological conditions due to the reduction in the level of impoundment of water in the lake and low precipitation. In recent years, the reduction in phosphorus and chlorophyll concentrations and a slight increase in water transparency were noticeable, but they were still at a level corresponding to advanced eutrophy. 


\section{Acknowledgements}

We thank the authorities of Poznań University of Life Sciences for providing necessary facilities during the course of our researches. The study analysed the results of researches carried out in 1999-2002 under the project No. 607318 PO4G, financed by State Committee for Scientific Research, and in 2005-2008 under the project No. 2 P06S 026 28, financed by Ministry of Sciences and Informatisation.

\section{REFERENCES}

1. Atlas podziału hydrograficznego Polski. 2005. Czarnecka H. (red). IMGW Warszawa.

2. Carlson R.E. 1977. A trophic state index for lakes. Limnology and Oceanography, 22(2), 361-369.

3. Dyrektywa 91/676/EWG. Council Directive 91/676/EEC of 12 December 1991 concerning the protection of waters against pollution caused by nitrates from agricultural sources. Dz.U.UE.L.91.375.1 as amended.

4. Environment 2005. 2005. Statistical information and elaborations. Central Statistical Office, Warsaw [in Polish].

5. Environment 2014. 2014. Statistical information and elaborations. Central Statistical Office, Warsaw [in Polish].

6. Forsberg C., Ryding S.O. 1980. Eutrophication parameters and trophic state indices in 30 Swedish wastereceiving lakes. Arch. Hydrobiol., 89, 189-207.

7. Fotyma M., Duer I. 2006. Implementation of Nitrate Directive to Poland. Acta Agriculturae Slovenica, 87, 1, 51-58.

8. Galvez-Cloutier R., Sanchez M. 2007. Trophic status evaluation for 154 lakes in Quebec, Canada: Monitoring and recommendations. Water Qual. Res. J. 42, 4, 252-268.

9. Hillbricht-Ilkowska A. 1989. Różnorodność biologiczna siedlisk słodkowodnych - problem, potrzeby działania. Idee Ekol. Ser. Szkice, 13(7), 13-55.

10. Kajak Z. 1983. Dependences of chosen indices of structure and functioning of ecosystems of different trophic status and mictic type for 42 lakes. Ecological characteristics of lakes in north-eastern Poland versus their trophic gradient. Ekologia Polska, 31, 495-530.

11. Karaczun, Z. 2005. Preparing for EU environmental policy in Poland: the case of the nitrates directive. Land Use Policy, 22, 245-253.

12. Kondracki J. 2002. Geografia regionalna Polski. PWN, Warszawa.

13. Ławniczak A.E., Choiński A., Kurzyca I. 2011. Dynamics of lake morphometry and bathymetry in various hydrological conditions. Polish Journal of Environmental Study, 20 (4), 931-940.

14. Murat-Błażejewska S., Zbierska J., Ławniczak A., Kanclerz J., Kupiec J., Sojka M. 2008. Eksploatacja urządzeń wodnych a zasoby wodne zlewni nizinnej. Acta Scientiarum Polonorum, Architectura, $7(2), 13-22$.

15. Nürnberg G. 2001. Eutrophication and trophic state. LakeLine, 29(1), 29-33.

16. OECD 1982. Eutrophication of waters. Monitoring assessment and control. Technical report.

17. OECD 2003. Environmental Performance Reviews - Poland. Paris, France,

18. OECD 2008. Wpływ rolnictwa na środowisko naturalne od 1990 r. Raport Główny. Paryż, Francja. http://www.oecd.org/poland/40806009.pdf

19. Pełechata A., Pełechaty M., Pukacz A. 2006. An attempt to the trophic status assessment of the lakes of Lubuskie Lakeland. Limnological review, 6, 239-246.

20. Rozporządzenie Dyrektora Regionalnego Zarządu Gospodarki Wodnej w Poznaniu z dnia 2 grudnia 2003 roku w sprawie określenia wód wrażliwych na zanieczyszczenia związkami azotu ze źródeł rolniczych oraz obszarów szczególnie narażonych, z których odpływ azotu ze źródeł rolniczych do tych wód należy ograniczyć. Dz. Urz. Woj. Wlkp. nr 192, poz. 3568.

21. Rozporządzenie Dyrektora Regionalnego Zarządu Gospodarki Wodnej w Poznaniu z dnia 31 marca 2004 roku w sprawie programu działań mających na celu ograniczenie odpływu azotu ze źródeł rolniczych dla obszaru zlewni rzek Samica Stęszewska i Mogilnica. Dz. Urz. Woj. Wlkp. nr 51, poz. 1173.

22. Rozporządzenie Dyrektora Regionalnego Zarządu Gospodarki Wodnej w Poznaniu z dnia 4 kwietnia 2008 r. w sprawie określenia wód wrażliwych na zanieczyszczenie związkami azotu ze źródeł rolniczych oraz obszarów szczególnie narażonych, z których odpływ azotu ze źródeł rolniczych do tych wód należy ograniczyć. Dz. Urz. Woj. Wlkp. nr 57, poz. 1128.

23. Rozporządzenie Dyrektora Regionalnego Zarządu Gospodarki Wodnej w Poznaniu z dnia 7 kwietnia 2008 r. w sprawie programu działań mających na celu ograniczenie odpływu azotu ze źródeł rolniczych dla obszaru szczególnie narażonego Samica Stęszewska i Mogilnica. Dz. Urz. Woj. Wlkp. nr 66, poz. 1298.

24. Rozporządzenie Ministra Środowiska z dnia 23 grudnia 2002 r. w sprawie kryteriów wyznaczania wód wrażliwych na zanieczyszczenie związkami azotu ze źródeł rolniczych. Dz.U. 2002 Nr 241, poz. 2093.

25. Soszka H. 2009. Problemy metodyczne związane o oceną stopnia eutrofizacji jezior na potrzeby wyznaczania stref wrażliwych na azotany. WodaŚrodowisko-Obszary wiejskie. 9, 1(25), 151-159. 
26. Szymański D., Dunalska J., Brzozoska R., Sieńska J. Zieliński R. 2014. Ocena stanu troficznego jezior miejskich Olsztyna na podstawie indeksu Carlsona. [W:] Traczewska T.M., Kaźmierczak B. (Reds). Interdyscyplinarne zagadnienia $\mathrm{w}$ inżynierii $\mathrm{i}$ ochronie środowiska. Vol. 4. Ofic. Wyd. Polit. Wroc. Wrocław, 872-880.

27.Zbierska J., Kupiec J. 2004. Ekologiczne skutki obniżenia poziomu wody w Jeziorze Niepruszewskim. Zesz. Nauk. AR Kraków, Inżynieria Środowiska, 25, 21-30.

28. Zbierska J., Lawniczak A., Kupiec J., Mastyński J., Zbierska A. 2011. Koncepcja ochrony i rekultywacji Jeziora Niepruszewskiego i Jeziora Tomickiego. Manuscript, Department of Ecology and Environmental Protection, PULS Poznań [in Polish]. 